\title{
WATER RESOURCES OF THE UNITED STATES
}

\begin{abstract}
A s. $S$ a result of Senate Resolution No. 48 of the Eighty-sixth Congress of the United States, a Select Committee on National Water Resources was set up in 1959 to study the extent and character of water resources activities required to provide the future quantity and quality of water needed for all segments of the economy in the United States.

Under the vigorous leadership of Senator Robert S. Kerr from Oklahoma, this Committee has now completed its assignment and presented its final report and recommendations to the first session of the Eighty-seventh Congress. The final report was preceded by a series of specialist reports which have
\end{abstract}

List of Committee Prints issued by the Select Committee on Nationa Water Resources, U.S. Senate, 1959-60, under the title Water
Resources Activities in the United States, Obtainable from the Govern ment Printing Office, Washington

$$
\text { (A) BACKGROUND }
$$

1. Water Facts and Problems, U.S. Geological Survey.

* 2. Reviews of National Water Resources during the Past Fifty Years. Legislature Reference Service, Library of Congress.

* 3. National Water Resources and Problems, U.S. Geological Survey

4. Surface

* 5. Survey

5. Population Projections and Economic Assumptions, Census

States, State reports on their water

\section{(B) Projections of Future NeED}

* 7. Future Water Requirements for Municipal Use, Public Health Service.

8. Future Water Requirements of Principal Water-Using Industries, Business and Defence Services Administration and Bureau of Mines.

* 9. Pollution Abatement, Public Health Service.

10. Electric Power in Relation to the Nation's Water Resources, Federal Power Commission and others.

11. Future Needs for Navigation, Corps of Engineers, U.S. Army.

* 12. Land and Water Potentials and Future Requirements for Water, Department of Agriculture.

* 13. Estimated Water Requirements for Agricultural Purposes and their Effects on Water Supplies, Department of Agriculture.

14. Future Needs for Reclamation in the Western States, Bureau of Reclamation.

15. Floods and Flood Control, Corps of Engineers, U.S. Army.

* 16. Flood Problems and Management in the Tennessee River Basin. Tennessee Valley Authority.

17. Water Recreation Needs in the United States, National Park

18. Fish and Wildlife and Water Resources, Fish and Wildife Service * 19. Water Resources of Alaska, U.S. Department of the Interior.

(C) Techniques for Maeting Needs

*21. Evapo-Transpiration Reduction, Department of the Interior and Department of Agriculture.

* 22. Weather Modification. Weather Bureau and Dean A. M. Eberle.

* 23. Evaporation Reduction and Seepage Control, Bureau of Reclamation.

* 24. Water Quality Management, Public Health Service.

* 25. River Forecasting and Hydrometeorological Analysis, Weather Bureau.

* 26. Saline Water Conversion, Office of Saline Water, Department of

* 27. Application and Effects of Nuclear Energy, Atomic Energy Com-

* 28. Water Resources Research Needs, Department of Agriculture.

29. Water Requirements for Pollution Abatement, Prof. George Reid, University of Oklahoma.

30. Present and Prospective Means for Improved Re-use of Water, Abel Wolman Associates.

31. The Impact of New Techniques on Integrated Multiple-Purpose E. A. Ackerman and Associates.

32. The Supply and Demand of Water in the United States, Dr. The the Future.

(D) HEarings of Evidence

Hearings Held by the Select Committee on National Water Resources and published in 23 parts with index. Pp. 3968. (Washington, 1960.)

(E) FINAX REPORT AND RECOMMENDATIONS

Report of the Select Committee on National Water Resources, Report No. 29 of the First Session of the Eighty-seventh Congress, 1961. been appearing steadily over the past two years. A number of these reports has already been reviewed in Nature $(187,562 ; 1960)$, and have been marked with an asterisk in the now complete list given here. Many of these reports and also the final recommendations will be of interest to those faced with water problems in the United Kingdom and Commonwealth, as well as elsewhere. A brief outline of the salient points of the new reports and the final recommendations therefore follows.

Committee Print No. 1 consists of copies of the charts prepared by the U.S. Geological Survey on the occasion of the presentation of an account of the water resources and related problems of the United States at a meeting in July 1959. Much of the material in this report is also covered in Print No. 3, which has already been reviewed.

Committee Print No. 5 contains the population projections and economic assumptions on which the studies for the water resources committee are based. This report is of considerable interest and has wider implications beyond that of the water problem. The first part predicts that the population of the United States will reach between 225 and 278 million by 1980 , and between 267 and 431 million by the year 2000. Breakdowns of these projections by States and water resource regions, and between urban and rural areas in each water resource region are given. The report covers projections made by the U.S. Census Bureau, the Committee Staff and 'Resources for the Future', a private organization.

Committee Print No. 6 is a voluminous report detailing the views and comments of each State on the water problem. The replies received from the invitation to submit evidence range from brief letters to elaborate treatises from States where water is an acute problem. Taken as a whole the responses provide a valuable background to the national problem.

Report Nos. 8, 10 and 11 form a natural group dealing with industry, electricity and navigation, respectively. Committee Print No. 8 attempts an assessment of the future water requirements of the principal water-using industries. The 1954 census showed a total use of water of more than $12,000 \times 10^{8}$ gal. annually in the primary manufacturing industries, exclusive of electric power generation. The Department of Commerce estimates that the 1954 intake of $7,700 \times 10^{\circ} \mathrm{gal}$. for the iron and steel, chemical, pulp and paper, food and beverage, alumin. ium and copper industries could rise to $26,500 \times 10^{9}$ gal. by 1980 and $61,600 \times 10^{2}$ gal. by the year 2000 . The Bureau of Mines projects water intake in the mining industries from $1,790 \times 10^{9}$ gal. in 1954 to $3,765 \times 10^{9}$ gal. in 1980 and $4,770 \times 10^{9}$ gal. in the year 2000. Taking all industries exclusive of electric power together, a total need of water of up to $36,500 \times$ $10^{9}$ gal. a year by 1980 and double this amount by the year 2000 is estimated. Committee Print No. 10 deals with the needs of the electric power industry, and it is not surprising to see oven more astronomical figures. During 1959 about $26,813 \times 10^{9}$ 
gal. of water were circulated in thermal plants of investor-owned systems. By 1980 these will need $106,409 \times 10^{9}$ gal. yearly. To this must be added the needs of nuclear power plants and the rural electrification schemes of the Department of Agriculture. Fortunately, from the point of view of national water supplies, most of this water is needed for cooling purposes, and less than 1 per cent is a consumptive use. The same consideration also applies to hydro-electric developments: the report shows that present hydropower eapacity represents between one-quarter and one-third of the actual and economic water-power potential, and that the overall resource limitation on hydro development in the United States is not yet within sight. Committee Print No. 11 details the future needs for inland navigation. This report covers briefly the history of navigation on the inland waterways system of the United States (which extends to some 20,000 miles), gives an inventory of the present system, and discusses possible improvements and extensions thereto in the light of the estimates that freight traffic will double by 1980 and quadruple by the year 2000 . The improvement of some 10,041 miles of existing waterways and the creation of some 3,070 new waterways might eventually be needed.

Committee Print No. 14 investigates the future water needs for reclamation in seventeen Western States. These States have had in recent years a more rapid growth in population and economic activity than the United States as a whole, and the trend is likely to continue. The Bureau of Reclamation, which has been responsible for much of this development, was asked, therefore, to report on anticipated future developments of reclamation in the Western States between now and the year 2000, including Federal, State and local projects. In preparing its report, the Bureau has inventoried more than 1,000 projects, of which it estimates that some 800 will be realized by the year 2000, bringing in 17 million acres of newly irrigated land and creating 230,000 family-sized farms for an 'on-farm' population of 800,000 . This could support a local non-farm population of 2.4 million and provide food and fibre for 25 million people. The full efficient utilization of water resources in the Western States would require significant changes in existing patterns of use of water. Many involved water exchanges would have to be worked out, the State laws with respect to ground water would need modification, a good deal of research on the hydrological cycle would be necessary and many financial problems would need resolution. Appendixes to the report include maps and charts showing the location and construction costs of the 1,085 projects. This report has proved to be one of the most interesting, stimulating and also challenging accounts of the whole series.

Committee Print No. 15 discusses the flood problems of the United States, tabulates past and expected future flood damage by river basins, presents the historical and legislative background of flood control in the United States, and considers possible solutions for flood problems in the light of the fact that overall flood damage is increasing more rapidly than it has been possible to reduce it by the construction of control works. Three alternative methods of reducing damage exist: (a) abandonment or evacuation of flood plains; (b) regulation of flood plain use to accommodate the use to the flood hazard; (c) provision of works and measures for flood protection or control. The report presents an inventory of works and projects needed to prevent flood damage in the foreseeable future until 1980 . These works include more than 64 million acre-feet of flood control storage in reservoirs, 4,300 miles of levees and flood walls, and 5,900 miles of channel improvements.

Committee Prints Nos. 17 and 18 serve as salutary reminders that the water problem is not confined to industrial and agricultural interests. The rapidly rising demand for ou door recreation by an expanding population with a rising standard of living is con. sidered in Report No. 17. There are few outdoor activities from which water is absent, and the report sets forth recommendations from the National Park Service regarding future water recreation needs. It suggests that some 15 per cent of the oceanic and major inland water shoreline should be acquired, that certain free-flowing streams the recreational value of which outweighs other considerations should be preserved, that water reservoirs should where possible be made multi-purpose, that efforts to combat pollution should be increased. Little consumptive water is involved in the report, which is concerned mainly with the need for conservation of water for recreation. Committee Print No. 18 deals with a rather more specialized aspect of outdoor recreation-that of fish and wild life in relation to water resources. The report points out that the problem of maintaining fish and wild life resources are compounded by the combination of the rapidly increasing population and increase in leisure time together with the gradual and increasing encroachment of man's activities on the habitat available for fish and wild life. It is urged that fish and wild-fowl conservation and development should be considered as a co-equal purpose with other demands on water resources development in the United States.

Committee Print No. 29 on pollution abatement supplements Nos. 9 and 24 previously reviewed. One of the principal requirements for water in the future is for the dilution of effluent resulting from the treatment of municipal sewage and industrial wastes which are disposed of into rivers. Prof. Reid, who with the advice of technical experts from the Public Health Service, developed short-cut methods for estimating dilution water requirements, is largely responsible for report No. 29. The study is limited to the rivers in the 22 water resource regions delineated and excludes the problems of tidal estuaries. Waste loadings that would normally be discharged directly into the sea or large lakes were not considered.

Committee Print No. 30 is an important account of present and prospective means for the re-use of water. As demands for water rise, it becomes increasingly necessary for the public to use second-hand water. With all the indications pointing towards a three-fold increase in water withdrawal by 1980 , rising to a sixfold increase by the year 2000 , the need for improving techniques of water re-use is obviously urgent. The report indicates that already 70 million of the 117 million people now served by public water systems are re-using water that may have passed through a domestic sewage or industrial waste disposal plant at least once. The report is based on a review of several thousand technical papers: it presents methods of reclaiming water from sewage and industrial wastes, outlines the problems encountered in the re-use of water, goes into considerable detail on the restoration and maintenance of underground water 
supplies, covers ground water recharge, and reclamation of saline waters.

As a fitting companion to Committee Print No. 30 we find No. 31 dealing with the impact of new techniques on integrated multiple-purpose water development. To meet a situation within this century in which water requirements will cause the United States to go beyond the traditional approaches to water development, the report suggests a new type of approach termed "comprehensive development", which is defined as "the application of integrated multiple-purpose design, planning and management which includes joint consideration of ground and surface water, conservational and other measures for engineering of demand, and the treatment and management of water having a substandard quality". This report has been prepared under the direction of Dr. Edward A. Ackerman.

Finally, in Committee Print No. 32, we find a summary report on the estimated supply and demand for Water in the United States for 1980 and 2000 by "Resources for the Future". The basic projections and information supplied by the Federal agencies for each of the 22 regions into which the contiguous parts of the United States were divided for the purposes of the study has enabled tentative balance sheets of water supply and demand to be drawn up. The report also deals with the basic physical problems of providing the necessary facilities for storage and treatment of water. It shows very clearly the great economic advantages that could follow from the more complete treatment of wastes.

These reports, together with the hearings, occupy some 5,800 pages and provide a most detailed picture of the present practice of use of water in the United States, and of impending problems. The final report of the Select Committee on National Water Resources to the Senate (No. 29 of the Eighth-seventh Congress, First Session) summarizes the findings and gives the Committee's conclusions and recommendations. The need for meeting problems before they arise is stressed, and five major categories of effort are thought desirable so as not to inhibit national or regional economic growth: $(a)$ regulating stream-flow through the construction of surface reservoirs and watershed management; $(b)$ improving the quality of streams through pollution abatement programmes; (c) making better use of underground storage; $(d)$ increasing the efficiency with which water is used through the elimination of wasteful practices, improved sewage treatment methods, recirculation, increased irrigation efficiency, and substitution of air for water cooling; (e) increasing the natural yield of water by desalting, weather modification, and other artificial means.

The Committee's main recommendations to Congress are accordingly:

(1) The Federal Government, in co-operation with the States, should prepare, and keep up to date, plans for comprehensive water development and management for all major river basins in the United States. The Executive Branch should be requested to submit plans to Congress in January 1962, for undertaking and completing such work in all basins by 1970 .

(2) The Federal Government should stimulate more active participation by the States in planning and undertaking water development and management activities by setting up a 10-year programme of grants for water resources planning.

(3) The Federal Government should undertake a co-ordinated scientific research programme on water. This should include both research into ways to increase available supplies and ways to increase efficiency in the use of water. The Executive Branch should be requested to submit a programme of research to Congress in January 1962.

(4) The Federal Government should prepare biennially an assessment of the water-supply demand outlook for each of the water resource regions of the United States. The Executive Branch should be requested to submit a programme of research to Congress in January 1962.

(5) The Federal Government, in co-operation with the States, should encourage efficiency in water development and use, by regulating flood plain use, by studying and anticipating water problems, by anticipating storage needs, by increasing public awareness of water problems and by the provision of public hearings where necessary.

Water is to-day assuming an ever-increasing importance as civilization's needs for water and waterrelated products and services grow. Areas of the globe that will thrive, or even survive, will be determined by the availability of water resources and their wise use to serve man. Growing communities will need increasingly to organize and conserve these resources. Commendable foresight has been shown in the United States in the efforts being made to provide adequate water supplies for the next generation. Most countries, especially the United Kingdom and many members of the Commonwealth, will find the approach, the reports, the findings and the recommendations of the Senate Select Committee which have been considered here of great value and interest to them in dealing with their own water problems.

W. G. V. BALChIN

\section{FLORA EUROPAA}

$\mathrm{T}$ HE second symposium of Flora Europæa was held during May 21-28, 1961, in Italy. It was divided into three parts, the first in Genoa, where five days were devoted to various papers and discussions, the second consisting of an excursion to Viareggio and the Apuane Alps, ending in Florence where the final sessions of the symposium were held in the Botanical Institute.

The meeting was attended by participants from Denmark, Switzerland, Sweden, Finland, Iceland, Poland, Portugal, Spain, Rumania, Germany, Yugo- slavia, Belgium, France, Austria, Norway, as well as Italy and by all the members of the British Editorial Committee.

In Genoa the symposium was held in the University Botanical Institute, founded by the British philanthropist and merchant, Thomas Hanbury, whose name the Institute still bears. The Institute is situated high above the city, surrounded by its Botanic Garden, and made a very appropriate and comfortable meeting placo. The arrangements were made by Prof. R. E. G. Pichi-Sermolli, director of the 